\title{
İnancın Deneyimsel Olanaklılığı
}

\section{Funda Neslioğlu Serin}

Özet: Bu çalışmada, bir yandan bilgiye yol açması bağlamında deneyimin inanca kaynak oluşturması, öte yandan insan edimlerine yol açması bağlamında inancın deneyimlenmesine olanak oluşturması nedeniyle inanç-deneyim ilişkisi irdelenecektir. İnanç-deneyim ilişkisinin olanakllığg 1 ve bu ilişkinin kuşkulu doğası, Davidson ve Wittgenstein gibi iki önde gelen çözümleyici filozofun konuyla ilgili açıklamaları dikkate alınarak araştırılmaktadır.Yazının ana savını şu temel fikir oluşturmaktadır: Sanılanın aksine, ne deneyimler inanç için sağlam ve kesin bir temel oluştururlar ne de deneyimler bilinmek için inançlara gereksinim duyarlar.

Anahtar Sözcükler: İnanç, deneyim, nedensellik, Donald Davidson, Ludwig Wittgenstein

\section{Empirical Possibility of Belief}

\begin{abstract}
In this paper, the relationship between belief and experience will be investigated because on the one hand, experience creates a source for beliefs which leads knowledge and on the other hand it makes the experience possible, which leads human actions. Considering the analysis of two prominent analytic philosophers Davidson and Wittgenstein, the relationship of belief and experience, and the questionable nature of this relationship will be studied. The basic claim of this paper consists of the following primary idea: Contrary to what is believed, neither experiences form a firm and certain basis for beliefs, nor experiences are in need of beliefs to be known.
\end{abstract}

Keywords: Belief, experience, causality, Donald Davidson, Ludwig Wittgenstein

İnanç ve deneyim arasındaki ilişkinin doğasının sorgulanması, iki türlü sonuçlanabilir: İnancın geçerliliği açısından deneyimin gerekmemesi ya da deneyimin somutluğu açısından inancın temelsiz olması. İlk seçenek, inancı dogmatik olmaya iten bir eğilim iken, ikinci seçenek inancı deneyime kapalı kılması nedeniyle en iyi olasılıkla inancı bireyselleştirmektedir.Bu yazıda, inancın gerekçelendirilmesinde başvurulan salt deneyimin bilginin kaynağı olup olamayacağına yönelik tartışmalardan yola çıkarak, inancı deneyimlemenin olanaklı olup olmadığı soruşturulacaktır. Bu çerçevede çözümlemeci felsefenin önde gelen iki üyesi Davidson ile Witgenstein'ın görüşlerine başvurulacaktır. İlkinin, edime yolaçması bağlamında

Neslioğlu Serin, Funda (2016) “İnancın Deneyimsel Olanaklılı̆̆ı”, Kilikya Felsefe Dergisi, (1) s. 64-73 
inancın doğasıyla ilgili ortaya koyduğu açıklamaları; ikincinin, bilginin temellendirilmesine yönelik savları kesinlik açısından eleştirileriyle birlikte irdelenecektir.

Çağdaş bilgi kuramlarında bilginin neliğine ilişkin verilen tanımlar ve yapılan çözümlemeler, genel olarak, bilgiye yolaçan inancın doğruluğunun gerekçelendirilmesi ve bunu sağlayacak koşulların belirlenmesini içerir. Öncelikle E. Gettier'in “Is Justified True Belief Knowledge?" (1963, s. 1213) (Gerekçelendirilmiş Doğru İnanç Bilgi midir?) başlıklı makalesinde bilginin gerekçelendirilmesine dair süreçleri daha açık hale getirme çabası ve bu amaçla öne sürdüğü açıklama ve koşullar, ardından bunların bile bilgi için yetersiz olduğuna değinen sonraki dönemlerdeki bazı çalışmalar, gerekçelendirme işleminin düşünüldüğünden daha çetrefilli bir sorun olduğunu gözler önüne serdi.

Gerekçelendirilmiş doğru-inancın bilgi olup olamayacağ1 sorunu, sadece gerekçelendirme işleminin doğasını değil, doğrunun ne olduğu, gerçeklik ile ilişkisi, bağlam, vb. konuların da tartışılmasını gerektirir. Bir inancın ya da bir yargının doğru olması, uygun ve/veya yeterli kanıtlarla gerekçelendirilmiş olması demektir. Burada başvurulan "doğru" kavramı ise, gerekçelendirme işleminin daha çok neyi temele aldığıyla yakından ilişkilidir. Bilgi kuramında gerçekçilik yaklaşımını benimseyen felsefeciler,evrendeki olguları iyi temsil ediyor olmasından dolayı tekil olanın gerekçelendirmede temele alınması gerektiğini savunur. ${ }^{1}$ Başka bir deyişle, bir inancın ya da yargının, algılanabilir ve/ veya deneyimlenebilir olana başvurmaksızın gerekçelendirilebilmesi olanaklı değildir. Burada asıl sorun, inançların diş-dünya ve deneyimle ilgisinin ya da ilişkisinin ne olduğudur. Diğger yandan, dış-dünyaya ilişkin hiçbir inancin gerekçelendirilemeyeceğini savunan kimi kuşkucular, deneyimin bu türden inançlar için dayanak oluşturabilmesinin olanaksız olduğunu belirtmişlerdir. Başka bir yaklaşıma göre ise, deneyim sadece içgözlemsel inançlar (introspective belief) için dayanak olabilir; bu durumda görgül (empiric) bilgi ve algısal gerekçelendirme, iç-gözlemsel inançtan dış-dünyaya ilişkin inanca uzanan ve sürekli bir yeniden yapılandırmayı da imleyen bir çıkarsamadan ibarettir. İç-gözlemsel inançlardan dışdünyaya ilişkin inançlar alanına bu türden bir geçiş, hem ussallık hem de gerçekçilik açısından pek çok sorunu da beraberinde getirir. Bunlardan birini Donald Davidson dile getirmiştir; deneyimin inanç olmadı̆̆ı, inançlarla sadece başka inançların gerekçelendirebileceğini öne süren

\footnotetext{
${ }^{1}$ Örneğin;B. Russell, G.E. Moore, G.Ryle
} 
Davidson'a göre, deneyimden inanca geçiş ussal değil, nedenseldir (causal) (Davidson 1986, s. 310). Dolayısıyla deneyimleri temel alarak herhangi bir inancın gerekçelendirilmesi, bir deneyimin değil, aslında inançların başka inançlarla gerekçelendirilmesinden ibarettir. ${ }^{2}$

Bir duyum ile bir inanç arasındaki bağıntı mantıksal olamaz, çünkü duyumlar, inanç ya da önermesel durumlar değillerdir. O halde bağıntı nedir? Bence cevap açıktır: bağıntı, nedenseldir. Duyumlar, bazı inançlara neden olurlar ve bu bakımdan da o inançların temeli ya da dayanağıdır. Ancak bir inancın nedensel olarak bir açıklaması, inancın nasıl ya da neden gerekçelendirildiğini göstermez (Davidson 1986, s. 307).

Davidson'ın inancın gerekçelendirilmesinde deneyimin rolüne dair saptamasının doğurduğu bir sonuç da, bilgiye yol açması bağlamında daha çok deneyimden inanca doğrultusunda ele alınan inanç-deneyim ilişkisinin yanı sıra, inancın deneyimlenmesi bağlamında inançtan deneyime doğru ilerleyen inanç-deneyim ilişkisiyle ilgilidir. Başka bir ifadeyle söylemek gerekirse, somut-deneyim ile doğru-inanç arasında varsayılan ilişki, sadece bu iki unsurun birbirine yalın bir uygunluğunda değil, somut deneyime neden oluşturması bağlamında inancın belli bir biçimde deneyimlenmesi olarak da sorgusunu gerektirir. Somut deneyime yol açması dolayımıyla inancın sorgulanması ise, edim (action) konusunda yapılan tartışmalarla yakından ilişkilidir. İnsan edimlerinin ne olduğu ve nasıl gerçekleştiğine ilişkin görüşlerini ortaya koyduğu "Actions, Reasons, and Causes" başlıklı yazısında Davidson, edimlerin gerekçelere gönderme yaparak ortaya konan açıklamalarının nedensel açıklamanın bir türü olacağını öne sürer (Davidson 2001, s. 3-21). Ancak bu noktada Davidson, gerekçelerin, o edimlerin nedenleri olduğu kadarıyla edimleri açıklayabileceğine özellikle dikkat çeker. Bu yaklaşım, bir yandan olguları edim yapan temel özelliğin ussal olarak açıklanabilirlik olduğunu kabul ederken, diğer yandan bunun yeterli olmadığını da ima etmektedir. Davidson bu yaklaşımını kendi sözleriyle şöyle ortaya koyar:

\footnotetext{
${ }^{2}$ Bir inancın geçerliliğ̆ini saptamada inanç-deneyim ilişkisi Davidson'ın belirttiği gibi ussal ya da mantıksal değil de nedensel (casual) ise, bu durum bir yandan da inancın doğruluğunu belirlemede deneyimin sandığımız türde bir işlevi olmadığını gösterir. Gelinen bu nokta, W.V. Quine'ın “Epistemology Naturalized” başlıklı makalesinde savunduğu, bilgi için bir temel arama çabasından vazgeçmek yönündeki uslamlamasında haklı olabileceğini göstermektedir. Quine'ın doğalcı yaklaşımı uyarınca inanç-deneyim ilişkisi, bilgi kuramsal bir sorun olmaktan çıkmış ve dolayısıyla felsefenin değil, artık bir olgu olarak doğa bilimlerinin, bilginin temelleri sorununa işaret etmesinden dolayı da daha çok bilişsel psikolojinin ilgi alanına girmiştir.
} 
Ereksel olmayan açıklamaların, ussal nedenlerin sağladığ1 gerekçelendirme öğesini ortaya koymadığını kaydeden bazı felsefeciler, fiziksel neden kavramının başka yerdeki haliyle ussal nedenler ile edimler arasındaki ilişkiye uygulanamayacağ1 ve gerekçelendirme şablonunun, ussal nedenler durumunda, gereken açıklamayı sağladığı sonucuna varmışlardır. Ama, edimleri açıkladığımız sırada yalnızca ussal nedenlerin onları gerekçelendirdiğini kabul ettiğimizi varsayın; bundan, açıklamanın da ayrıca -ve zorunlu olarak- fiziksel yönden nedensel olacağ1 çıkmaz. Aslında ilk ussal nedenler, başka tür açılamalardan ayrı olarak ussallaştırmalar kurmaya yardımcı olmak üzere tasarlanmaktadır. Ussallaştırma, öne sürmek istediğim üzere, nedensel açıklamanın bir türü ise, o halde gerekçelendirme, mevcut anlamında, en azından ayırdedici olan bir özelliktir. Gerekçelendirmenin bir tür açıklama olduğu, böylelikle olağan fiziksel neden kavramını işe karıştırmaya gerek olmadığına dair öteki sava ne demeli? Bu noktada gerekçelendirmeye neyin dahil edildiğine karar vermek gerekiyor. Yalnızca istenen kadarı, edimin ussalığı gözönüne alındığında eyleyenin birtakım inançlara ve tutumlara sahip olmasını kapsayacak kadarı kabul edilebilirdi. Ama o zaman da zorunlu olan bir şeyler kesinlikle dışarıda kalmış oluyor; zira bir kişinin, bir edim için ussal bir nedeni olabilir ve edimi gerçekleştirebilir, ama gene de bu ussal neden, edimi yapma nedeni olmayabilir. Ussal bir neden ile açıklamasını yaptığı bir edim arasındaki ilişkinin göbeğinde yer alan şey; eyleyen edimi gerçekleştirir, çünkü eyleyenin ussal gerekçesi vardır düşüncesidir. Elbette bu düşünceyi de temellendirmeye dahil edebiliriz; ama o zaman gerekçelendirme kavramı, söz konusu “çünkü"nün gücünün hesabını verene dek, us kavramının kendisi kadar karanlık hale gelir (Davidson 2001, s.9).

İnancın insan edimleri için ussal neden (reason) ya da fiziksel neden (cause) sayılıp sayılamayacağı konusu, edim felsefesinde tartışılan bir nokta olmakla birlikte, öncelikle inancın ve edimin ne olduğunun açık hale getirilmesini gerektirir. "İstemli insan hareketleri" olarak tanımlayabileceğimiz edimler, bu yönüyle diğer tüm insan hareketlerinden ayrıldıkları öne sürülür. Dolayısıyla bir insan ediminin belli bir amaç ya da yönelmişlikle gerçekleştirilmiş olması, edimin temel niteliği olarak belirir. Bu noktada istem kavramının, edimlere neden olması bağlamında inançlar, arzular, istekler, niyetler, yönelmişlikler, vb. tüm unsurları 
kapsayan bir anlamda kullanıldığını vurgulamak gerek. Öte yandan geleneksel bakışın bir yansıması olarak ortaya konan istem-edim ilişkisine yönelik bu türden bir ele alış, yani istemin bir olgu ya da neden olarak tanımlanması, mantıksal olarak güçlükler de doğurmaktadır. Örneğin, edimlerin nedeni olarak istemin kendisi de bir olguysa eğer, bu durumda sözkonusu isteme yolaçan başka bir istemin olması gerekecek ve bu da sonsuz bir geriye gidiş anlamına gelecektir.

Davidson'a göre mantık açısından bakıldığında ortada mantıksal bir sorun olarak saptayabileceğimiz bir nokta bulunmamaktadır. Çünkü her şeyden önce nedensellik, olgular arasında olan bir ilişkidir;diğer yandan mantıksal ilişkiler son tahlilde olgu betimleri (descriptions) arasındaki ilişkilerdir (Davidson 2001, s. 12-3). Başka bir deyişle, ussal nedenler (reasons) ile edimler arasındaki ilişki mantıksaldır, ancak nedensellik ile bağlı olan olgular arasında mantıksal ilişki yoktur.

İstemin bir olgu sayılıp sayılamayacağı, sayıldığı ve zihinsel olgu olarak sınıflandırıldığında ise, fiziksel olanın fiziksel olmayan bir unsur tarafından nasıl harekete geçirilebildiği ya da yönlendirilebildiği sorusu da başka bir tartışmaya işaret etmektedir. Davidson tam da bu yüzden, "Actions, Reasons, and Causes" başlıklı yazısında, istemli edimlerin doğasını değil, daha çok edimlerin ussal nedenlerinin doğasının irdelenmesi gerektiğini savunur. Bir yandan da istemli edimin ne olduğunun açıklanmasının, ister istemez ussal bir nedenle edimde bulunmanın da açıklama gereğini doğurduğundan sözeder. Davidson bir ussal neden uyarınca edimin bir açıklamasını ortaya koyarken, eyleyicinin ediminin belli bir yönde gerçekleştirmesinin ussal nedeninin, o edimin o yönde gerçekleşeceğine dair bir inanç ile birlikte tutum-öncesi (proattitude) olarak adlandırdığı bir duruma dayandığını öne sürer. Bu türden bir inanç ve istem bileşimini de "birincil ussal neden" (primary reason) olarak tanımlar. Davidson'a göre, birincil ussal nedenler, edimlerin fiziksel nedenleridir (Davidson 2001, s. 3-4). Tam da bu nedenle inançlar ve istemlerin kendileri her ne kadar birer olgu olmasalar da, ortaya çıkışları dolayımıyla birer olgudurlar. Bu da nedensellik ilişkisi için olgu olma gereğinin sağlandığı anlamına gelmektedir.

Edimlerin nedensellik ilişkisi ile bağlandığ da olsa olgusallığını savunan Davidson'ın bu yaklaşımı, her ne kadar kendisi böyle tanımlamasa da, Richard Schantz'ın ifadesiyle "dolaysız gerçekçilik" in bir örneğidir (Schantz 1999, s. 185). Bilgisel gerekçelendirme 
süreçlerini dikkate aldığımızda, Davidson'a göre, duyu organlarımızda olup bitenlerin bu süreç içerisinde herhangi bir rolü olduğu düşünülemez. Duyusal uyarımların ve hatta genel olarak deneyimlerin, diş dünyaya ait olay ve nesneler ile onlara dair inançlar arasında fiziksel nedenselliği vareden araçlar olarak sıklıkla düşünüldügü bir gerçektir. Oysa Davidson, bir deneyimin sahip olunan bir inancın gerekçesi olamayacağı gibi, o inancın gerekçelendirilmesinde de herhangi bir etkisinin olmayacağını düşünür. Deneyime, inançlarımız ile nesnel dünya arasında bilgisel bir aracılık rolü yüklemenin güvenilir bir gerekçelendirme sağlamayacağ gibi, yol açtığ1 kuşkulu durum, üstesinden gelinmesi gereken yeni bir sorun olarak karşımızda belirmektedir. Bu saptamasının ardından Davidson'ın çözüm olarak bize sunduğu yol ise, "bildik nesnelerle aracısız teması yeniden oluşturmak"yönündedir (Davidson 1984, s. 198).

Karşı karşıya kaldığımız bir diğer sorun da, edimlerin nedensellik ilişkisi bağlamında, yani nedeni ve sonucu verilerek yapılan açıklamasında doğrudan ya da dolaylı olarak genel bir yasanın izlenip izlenmediğiyle ilgilidir. Daha açı ifade etmek gerekirse, olayların açıklamasını verirken, bunu genel bir yasaya dayandırarak yaparız ve bu yasa sözkonusu olaya ilişkin nedensellik ilişkilerini kapsar. Ancak edimlerin açıklamaları için de aynı işlemler uygulanmaya çalışıldığında, belli bir inancın ya da istemin, aynı nedensellik ilişkisiyle hep aynı edime yol açtığını varsaymak gereğiyle karşı karşıya kalırız. Oysa belli edimlere hep aynı inanç ve istemlerin neden olduğunu savunmak olanaklı değildir. Ancak Davidson'a göre, buradan hareketle inanç ve istemler ile edimler arasında nedensellik ilişkisinin olmadığı yönünde bir sonuç çıkarsayamayız. Davidson, bunun en temel gerekçesini, nedensellik ilişkisi içerisinde olup, "neden" ve "sonuç" olarak betimlediğimiz olayların bile zaten yasalarla birbirine bağlı olmayışına dayandırır.

Davidson'ın yasalara ilişkin sözkonusu saptayımı, bir yandan bilginin kaynağı olarak somut-deneyimi güvenilmez kıldığı gibi, diğer yandan da inancın deneyimlenmesi bağlamında inanç-deneyim ilişkisini daha çok bireysellik sınırları içerisine çekmiş görünüyor. Bu durumda sözgelimi eyleyicinin eyleme geçerken nasıl karar verebildiği ve tercihlerini neye dayanarak yapabildiği, önemli bir sorun olarak ortaya çıar. Bu noktayla ilgili olarak, 1950'lerde Patric Suppes ile birlikte Davidson'ın yürüttüğü "Karar Kuramı"na (Decision Theory) yönelik deneysel çalı̧̧malarda, eyleyicinin inanç ve tercihlerinin diğer inanç ve tercihlerinden ayrıştırmanın olanaksız olduğu sonucuna varmışlardı (Davidson, Suppes, 
Siegel 1957). Yani eyleyicinin bir ediminde ne istediği ya da ne yapmaya çalıştığını çözümlemenin, başka bir ifadeyle edimi betimlemenin her zaman birden çok yolu olacaktır. Davidson'ın uslamlamasına göre, deneysel verilere dayanarak bir edimin açıklamasını yapmaya çalışırken, aynı verinin çoklu sayıda açıklamayı, hatta birbiri ile uyuşmayanları bile aynı ölçüde desteklemesi olanaklıdır. ${ }^{3}$ Ancak bir yandan da, belli bir deneysel veriye dayanarak farklı açıklamaların sözkonusu olduğu böyle bir durumda, deneysel temellendirmenin geçerli olduğununu savunulamaz. Öte yandan sözkonusu saptayımın da ipuçlarını verdiği gibi, eyleyicinin edimine yasallık kazandıracak nitelikte zorunlu olarak yasal bir temellendirme yapılması, bir kısır döngüye de kapı aralamaktadır. Gelinen nokta itibari ile tümevarımın ilkece etkili bir araç olması beklense de, harekete geçirici bir konumu varmış gibi görünmemektedir. Öyleyse, edimin ereksel açıklamalarının doğa bilimlerine aktarılmasının güçlüğü de daha belirgin hale gelmiş olmaktadır. Bu noktada, ya istenenden zayıf ya da varolandan öte çok güçlü bir bağ kurma ikilemi ile karşı karşıyayız. Yani sağduyu, felsefe için oldukça basit kalmaktadır. Oysa felsefe sıklıkla sağduyuyu aşmaya kalkmaktadır.

Benzer bir uslamlamaya Ludwig Wittgenstein'da da rastlanır. Wittgenstein sorunu özellikle "kesinlik" konusu ile ilişkilendirerek tartışır. Deneyimin inançlarla bağının herhangi bir açıklamasını verirken izlenen uslamlamalarda yasallığı ve nesnel kesinliği sağlayabilecek ölçütlere başvurmanın olanaksızlığına değinir. Bu yaklaşımını oluşturan temel unsurlardan biri de, nedenselliğe dayalı açılamalar için ortaya koyduğu eleştirilerde gözlemlenebilir; Wittgenstein, fiziksel nedenselliğe dayalı açıklamalar alanında olmadığımızı ve bu tür açıklamaların da amaçlarımız bakımından kulağa önemsiz geldiğini belirtir (Wittgenstein 1993, s. 105). Dolayısıyla fiziksel nedensellik bağlamında inanç-deneyim ilişkisini betimleme ya da açıklama girişimleri, Wittgenstein açısından kuşkulu kalacaktır. Benzer bir yaklaşımı Wittgenstein Kesinlik Üstüne metninde de izler ve ussalcilar ile deneyimcilerin bilginin temeli olarak savundukları tüm uslamlamaları reddeder. Örneğin, Descartes'ın "Düşünüyorum, o halde varım." ve Moore'un "Bunun bir el olduğunu biliyorum." ${ }^{4}$ önermelerinde sanıldı̆̆1 gibi bir kesinliğin sözkonusu olamayacağını, dolayısıyla da sağduyu gerçekçiliğini temel alan bu tür önermelerden yola çıkarak kuşkuculuğun üstesinden gelinemeyeceğini

${ }^{3}$ Bkz. Davidson (1986), Essays on Actions and Events

${ }^{4}$ Wittgenstein tarafından eleştirilen Moore'un bu ve buna benzer diğer önermeleri "Proof of An External World" (s. 166) ve "A Defence of Common Sense" başlıklı makalelerinde geçmektedir. 
1srarla savunur.

'Bilgi' ve 'kesinlik' farklı kategorilere aittir. Bunlar sözgelimi ‘tahmin yürütme' ve 'emin olma'gibi iki 'zihin durumu' değildir. Burada “örneğin 'kuşku' sözcügüunün ne anlama geldiğini biliyorum" demenin benim için anlamlı olduğunu ve bu cümlenin 'kuşku' sözcüğüne mantıksal bir rol verdiğini kabul ediyorum. Şimdi bizi ilgilendiren, emin olma değil, bilgidir. Yani, eğer yarg1 vermek mümkün olacaksa, belli ampirik önermeler hakkında hiç kuşku olamayacağıyla ilgiliyiz. Ya da yine: ampirik önerme biçimindeki her şeyin ampirik önerme olmadığına inanma eğilimindeyim (KÜ $308) .^{5}$

Wittgenstein'a göre aslında "Biliyorum." derken, bilinen olgunun da kuşkusuz bir şekilde varlığı kabul edilmekte ve böylelikle olgu bir biçimde garanti edilmektedir (KÜ 12). Oysa herhangi bir yanılma olasılığını dahi yoksayan bu tutumun ya da garantinin neye dayanarak savunulduğunun gösterilmesi gerekir, yani Wittgenstein'ın ifadesiyle nesnel kesinlik olarak ortaya konmalıdır (KÜ 15). Öznel kesinliğin sağladığ açıklığı, nesnel kesinliğin açıklığı olarak kendiliğinden ve dolaysız biçimde benimsenebileceğini savunan Moore gibi sağduyu filozoflarının yaklaşımları, Wittgenstein açısından temelsiz bir güven duygusu eşliğinde ilerlemektedir. Zaten bedensel deneyimlerimizin, başkaca bir gerekçesi yoksa, doğurduğu inançlardan kuşkulanmıyoruz; sorun daha çok işin içinde bedenselliğin olmadığı (özneler-arasındacılık) nesnel alanda bu kuşkusuz olma, açık-seçikliği elde etmekle ilgilidir.

"Emin olma" ve "tahmin yürütme" yi zihinsel durumlar olarak ele alan Wittgenstein, bunların öznel kesinlik içerebileceklerini, ama "bilgi" olmayı sağlayabilecek nesnel kesinlikten yoksun olduklarını vurgular. Başka bir deyişle, Wittgenstein zihinsel durumların her ne kadar duyumları da içerdiğini söylüyor olsa da, "Biliyorum." gibi bir savın ileri sürülebilmesininancak "kesinlik" gibi aşkınsal bir koşulun sağlanmasıyla olanaklı görür. Bu durumda, eylemlerimize yol açması bağlamında inançların ve bunları kapsayan ilişkiler için kesinlik iddiası, öznel alanla sınırlı kalacaktır ve dolayısıyla öznel kesinlikten sözedilebilir olmasına rağmen "bilgi" olmasını sağlayacak türde nesnel bir kesinlik atfetmek için bir olanak sağlamayacaktır.

${ }^{5}$ Wittgenstein'ın Kesinlik Üstüne metni bundan sonra yazıdaKÜ olarak gösterilecek, alıntılar ve göndermeler paragraf numaralarıyla yapılacaktır. 
Tam bir kesinlikle eylemde bulunurum. Fakat bu kesinlik benim kendimindir (KÜ 174).

Bir başkasına "bunu biliyorum" derim; ve burada bir gerekçe vardır. Oysa inancım için yoktur (KÜ 175).

Bilmenin, inanç ya da deneyimlerin yolaçtı̆̆ı kuşkuları gidereceğini varsaymak felsefede yaygin tutumdur. Bu tutumun temelinde yatan sav, bilmenin kuşku içermesinin olanaksız olduğunun düşünülmesidir. Oysa Wittgenstein Kesinlik Üstüne metninde söz konusu bu yaygın tutumdan oldukça farklı bir yaklaşımsergilemektedir. Öncelikle bilmeyi zihinsel bir süreç ya da durum olarak görmek yerine, deneyimsel bir süreç olarak ele alır. Bu kabul, bilme ile kuşkuyu uzlaşmazlık içerisinde birlikte uyum içerisinde görür. Her ne kadar "bilmek" in hangi deneyime denk düştüğünü hiç bilmiyor olsak da deneyimlerimizi bildiğimizi söylemenin çelişik hiçbir yanı yoktur. Tıpkı matematikte hesabın ne demek olduğunu bilmeden hesaplama yapabiliyor oluşumuz gibibildiğimiz deneyimlerimiz olduğunu bildiğimizi düşünmeden deneyimlerimizi bilebiliyoruz. Oysa inançların bilgi-deneyim ikilisine benzer biçimde inanç-deneyim ikilisi oluşturması, inançların tanımı gereği olanaklı görünmüyor. Davidson'a göre -kuşkuculuğu göz önüne alsak da almasak da- doğruluğu önemsediğimiz sürece, ancak inanç-inanç ikilisi oluşturabiliriz. Bilmeyi zihinsel bir sürece dönüştürmek ise, Wittgenstein'dan da anlaşıldı̆̆ büsbütün olanaksız olduğu için,inanmanın özel bir tür bilgi olduğunu tanıtlamak, inançların deneyimlerle desteklenmesinin biricik yolu olarak görünmektedir.

Sonuç olarak, eyleyenin inançları öznel alanda bildikleri ile sınırlı olduğu sürece öznel deneyimler kadar açık seçik olacaktır. Oysa nesnel alanda olup bitenlerin hiçbiri inançlar kadar öznel alana uygun düşemeyeceğinden ötürü, nesnel alandaki deneyimler hiçbir inanç için temel oluşturamayacaktır. Dolayısıyla tutarlılığın arandığı herhangi bir inanç bu niteliğini korumak için eyleyicinin öznelliği ile sınırlandırılmaktadır. Bu sınırı aşan her inanç ya dogmatizme dönüşerek tutarsız inançlar halini alacak ya da nesnel alanın içerisinde eriyerek inanç olmaktan çıkacaktır.

Wittgenstein açısından edimin önce gelişi, inancın oluşumunda edimi aşan/edimdışı bir kaynağın varlığını bilgibilimsel açıdan olanaksız kılar. Böylesi bir alanın varlığına ilişkin bilginin her durumda edimsellikten 
gelen bir içerik gerektirmesi nedeniyle ister istemez inancın, geçmişin edimlerinin anımsanmasının ötesine geçemeyen durumlar olduğunu düşündürtmektedir. Dirimsel bir varlık olarak insanın edimlerinin her şeyin başlangıcında bulunuşu, inançların bu kaynaktan doğması gerektiğini benimsemeyi kolaylaştırsa da, çoğu inanışın basitçe geçmiş deneyimlerin kümelenmesi olamayacağı açıktır. Bir yandan aslolanın edim olduğunu Wittgenstein'ın bize anımsatışı, öte yandan inanmayı edimlere nedensellik bağıyla bağlamanın güçlüklerini Davidson'ın sergilemesi bize gösteriyor ki, inanç-deneyim sorunu, çağdaş felsefenin her iki cepheyi ancak uzlaştırarak üstesinden gelmesi gereken sorunlarından birisi olarak yerinde durmaktadir.

Funda Neslioğlu Serin, Ondokuz Mayıs Üniversitesi, Türkiye

\section{Kaynakça}

Davidson, Donald (1984). Inquiries into Truth and Interpretation, Clarendon Press: Oxford

Davidson, Donald (1986) "A Coherence Theory of Truth and Knowledge". Truth and Interpretation: Perspectives on the Philosophy of Donald Davidson içinde, (ed.) E. LePore. Blackwell: Oxford

Davidson, Donald (2001).Essays on Actions and Events: Philosophical Essays, Clarendon Press: Oxford

Davidson, Donald (2001). "Actions, Reasons and Causes", Essays on Actions and Events: Philosophical Essays, Vol 1. içinde, Clarendon Press: Oxford

Davidson, Donald; Suppes, Patrick; Siegel, Sidney (1957) Decision Making: An Experimental Approach. Stanford University Press: Stanford, CA

Gettier, Edmund L. (1963) “Is Justified True Belief Knowledge?", Analysis 23, s. 121123

Moore, G. E. (1993) "Proof of an External World,"içinde G. E. Moore: Selected Writings, (ed.) Thomas Baldwin, Routledge: London

Schantz, Richard (1999). "The Role of Sensory Experience in Epistemic Justification: A Problem for Coherentism", Erkenntnis, Cilt. 50, No. 2/3, s.177-191

Wittgenstein, Ludwig (1993) Philosophical Grammar, çev. Anthony Kenny, Basil Blackwell: Oxford

Wittgenstein, Ludwig (2009) Kesinlik Üstüne - Kültür ve Değer, çev. D. Şahiner, Metis Yayınları: İstanbul 